\title{
Retention of cesium and strontium by uranophane, $\mathrm{Ca}\left(\mathrm{UO}_{2}\right)_{2}\left(\mathrm{SiO}_{3} \mathrm{OH}\right)_{2} \cdot 5 \mathrm{H}_{2} \mathrm{O}$
}

\author{
Alexandra Espriu-Gascon ${ }^{\mathrm{a}}$, Javier Giménez ${ }^{\mathrm{a}, *}$, Ignasi Casas ${ }^{\mathrm{a}}$, Joan de Pablo ${ }^{\mathrm{a}, \mathrm{b}}$ \\ ${ }^{a}$ Department of Chemical Engineering, Barcelona Research Center in Multiscale Science and Engineering, Universitat Politècnica de Catalunya, Eduard Maristany, 10-14, 08019 Barcelona, Spain \\ ${ }^{\mathrm{b}}$ Fundació CTM Centre Tecnològic, Plaça de la Ciència 2, E-08243 Manresa, Spain
}

\section{A R T I CLE INFO}

\section{Keywords:}

Uranophane

Strontium

Cesium

Sorption

Spent nuclear fuel

\begin{abstract}
A B S T R A C T
This work determines the capacity of uranophane, one of the long-term uranyl secondary solid phases formed on the spent nuclear fuel (SNF), to retain radionuclides (cesium and strontium) released during the dissolution of the SNF. Sorption was fast in both cases, and uranophane had a high sorption capacity for both radionuclides (maximum sorption capacities of $1.53 \cdot 10^{-5} \mathrm{~mol} \mathrm{~m}^{-2}$ for cesium and $3.45 \cdot 10^{-3} \mathrm{molm}^{-2}$ for strontium). The high sorption capacity of uranophane highlights the importance of the formation of uranyl silicates as secondary phases during the SNF dissolution, especially in retaining the release of radionuclides not retarded by other mechanisms such as precipitation.
\end{abstract}

\section{Introduction}

In order to provide the safety assessment of a deep underground repository, long-term predictions on the release of radionuclides from the spent nuclear fuel (SNF) and their likely migration through the geosphere and biosphere are necessary. After the release of some mobile radionuclides from the SNF, the main mechanism for their retention before their incorporation to the biosphere is the sorption onto mineral phases. In particular, the formation of uranium(VI) secondary solid phases due to oxidative alteration processes of $\mathrm{UO}_{2}(\mathrm{~s})$ could have a key role in the retention of radionuclides in the near-field of the SNF.

Leaching experiments of SNF demonstrated the formation of a number of secondary solid phases depending on the chemical compositions of the leachates. In particular, in the presence of $\mathrm{Si}$, ubiquitously present in most groundwaters, uranyl silicates were found to be formed after the SNF dissolution. For instance, the SNF (burnups of 27 and $30 \mathrm{MWd} / \mathrm{kgU}$ ) leaching experiments carried out by Wilson with the so-called $\mathrm{J}-13$ water resulted in the formation of the uranyl silicates uranophane, $\mathrm{Ca}\left(\mathrm{UO}_{2}\right)_{2}\left(\mathrm{SiO}_{3} \mathrm{OH}\right)_{2} \cdot 5 \mathrm{H}_{2} \mathrm{O}$, and soddyite, $\left(\mathrm{UO}_{2}\right)_{2} \mathrm{SiO}_{4} \cdot 2 \mathrm{H}_{2} \mathrm{O}$, at $85^{\circ} \mathrm{C}$ [1-3]. With a similar water composition (EJ-13 water) and temperature $\left(90^{\circ} \mathrm{C}\right)$, leaching experiments with a SNF with burnups of 30 and $43 \mathrm{MWd} / \mathrm{kgU}$ carried out by Finn et al. [4] and Finch et al. [5] showed the formation of at least three uranyl silicates: soddyite, boltwoodite $\left(\mathrm{KUO}_{2}\left(\mathrm{SiO}_{3} \mathrm{OH}\right) \cdot \mathrm{H}_{2} \mathrm{O}\right)$ and uranophane. A mixture of these

\footnotetext{
* Corresponding author.

Email address: francisco.javier.gimenez@upc.edu (J. Giménez)
}

three uranyl silicates was also found in the contaminated sediments at the Hanford site [6].

One of the main effects of the formation of uranyl secondary solid phases is the possible incorporation of radionuclides released from the SNF through different mechanisms such as sorption or ionic exchange [7]. The sorption capacity of uranyl secondary solid phases was tested in different previous works and, in particular, some experiments were carried out in order to test the incorporation of some radionuclides to uranophane such as neptunium, strontium and cesium [8,9]. In such experiments, in uranophane synthesized in the presence of solutions which contained a certain amount of the radionuclide, it was actually incorporated at some extent to the uranophane lattice. These experiments could not identify the mechanism by which the radionuclides were incorporated to the solid. For this reason, the main objective of the present work is to determine the sorption capacity of uranophane through batch experiments consisting on mixing weights of the solid with solutions containing strontium or cesium.

On one hand, strontium was chosen because the ${ }^{90} \mathrm{Sr}$ isotope is considered one of the most important radioactive isotopes in the environment $[10,11]$, being of particular concern because of its high fission yield, its penetrating ionizing radiation $(\beta$ and $\gamma$ ) during the first several hundreds of years, and its chemical similarity to calcium which might be eventually replaced by strontium in human bones $[12,13]$. On the other hand, cesium was chosen because it is present in radioactive wastes as a fission product, and the ${ }^{135} \mathrm{Cs}$ (half-life: $3 \cdot 10^{6}$ years) and ${ }^{137} \mathrm{Cs}$ (half-life: 30 years) isotopes are considered harmful isotopes con- 
tributing to the radiation hazard of the nuclear waste [9]. In addition, due to the high solubility of most strontium and caesium solid phases, the most probable mechanism for their retention, once released from the nuclear waste, will be sorption on the uranyl secondary solid phases formed on the SNF surface or on mineral phases surrounding the repository.

\section{Experimental}

\subsection{Synthesis and characterization of uranophane}

Uranophane was synthesized following the procedure developed by Nguyen et al. [14]. Uranyl nitrate, calcium acetate and sodium silicate solutions were mixed together at $\mathrm{pH}=8$ and heated at $363 \mathrm{~K}$ for $24 \mathrm{~h}$. The solid phase obtained was later cleaned with Mili-Q water and introduced into a PARR reactor in contact with ultra-pure water for four weeks at $398 \mathrm{~K}$, in order to recrystallize the uranophane. Finally, the solid was filtered, rinsed with Mili-Q water and stored under dry conditions.

X-ray diffraction (XRD) and RAMAN spectroscopy showed that the solid was pure $\alpha$-uranophane. In addition, the solid synthesized had the typical needle shape morphology of uranophane [15] (see Fig. 1 for a microphotograph of the solid surface made with Scanning electron microscopy, SEM).

The specific surface area of the synthesized uranophane was determined following the BET methodology. The solid obtained from the synthesis was grinded and sieved, and the surface area for particles with less than $0.05 \mathrm{~mm}$ size was $33.42 \pm 0.06 \mathrm{~m}^{2} \mathrm{~g}^{-1}$.

The point of zero charge of the solid $\left(\mathrm{pH}_{\mathrm{pzc}}\right)$ was determined by using the so-called 'immersion methodology' [16-18]. $0.05 \mathrm{~g}$ of uranophane were immersed in $20 \mathrm{~cm}^{3}$ of a $0.01 \mathrm{~mol} \mathrm{dm}^{-3} \mathrm{NaCl}$ solution with a known initial pH (between 5 and 10, measured with a GLP-22 Crison 50-14 pH-meter). The equilibrium $\mathrm{pH}$ was measured after $24 \mathrm{~h}$ of contact. The variation of the equilibrium $\mathrm{pH}$ against initial $\mathrm{pH}$ (Fig. 2) showed a V-shaped curve. From the vertex of the curve, a $\mathrm{pH}_{\mathrm{pzc}}$ of $7.9 \pm 0.1$ was calculated. The value obtained was similar to the theoretical value calculated for uranophane, $\mathrm{pH}_{\mathrm{pzc}}=8,[16]$.

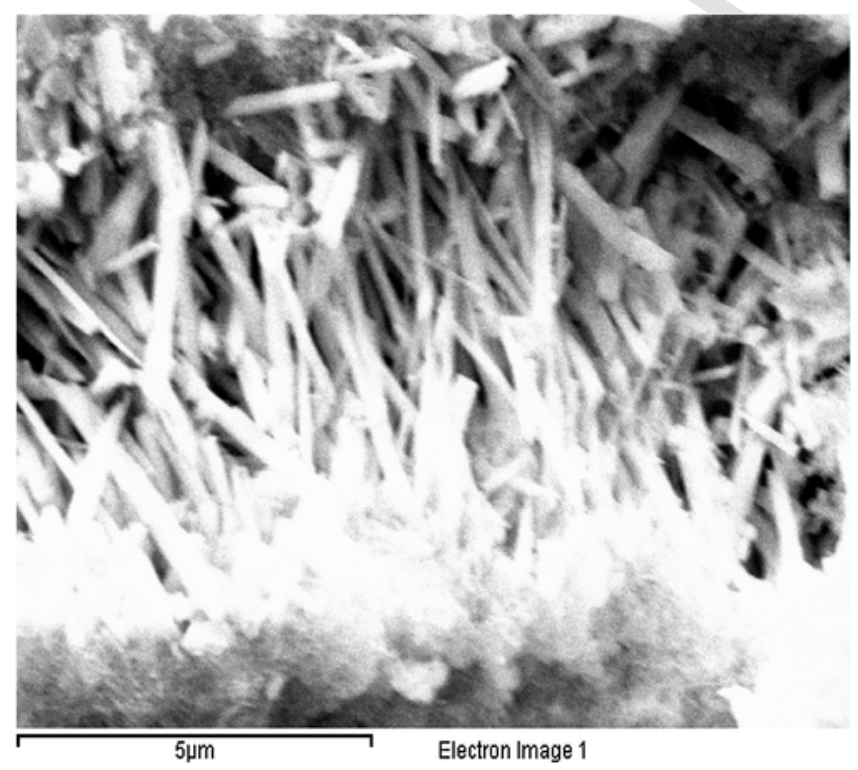

Fig. 1. Morphology of the synthesized solid determined by SEM.

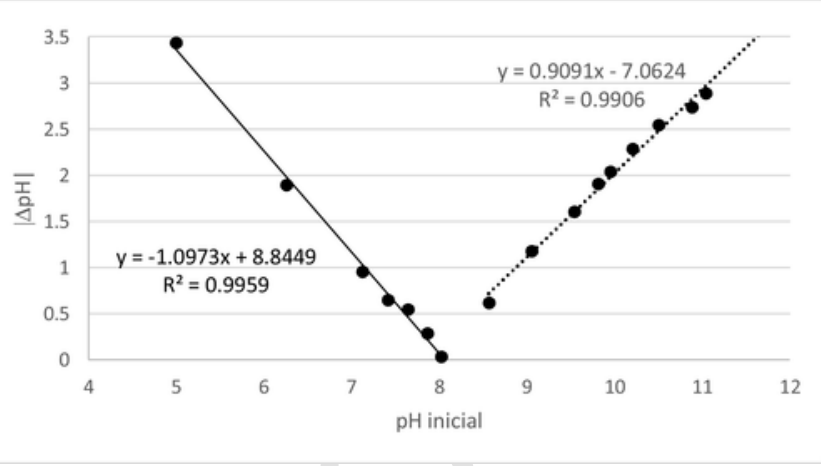

Fig. 2. Evolution of the solution $\mathrm{pH}$ as a function of the initial $\mathrm{pH}$ value.

\subsection{Experimental methodology}

Cesium and strontium solutions were prepared dissolving $\mathrm{CsClO}_{4}$ (Acros Organics) and $\mathrm{Sr}\left(\mathrm{NO}_{3}\right)_{2}$ (Merck) in Milli-Q water. Sorption batch experiments were carried out at room temperature and following the same methodology reported in previous works (see for example reference [19]). In short, $0.05 \mathrm{~g}$ of uranophane were put in contact with 20 $\mathrm{cm}^{3}$ of a strontium or cesium solution in polystyrene tubes. The tubes were continuously stirred until equilibrium was reached. At the end of the experiment, samples were taken and filtered through $0.22 \mu \mathrm{m}$ MICROPORE pore-size filters. Strontium and cesium concentrations in solution were determined by Inductively Coupled Plasma Mass Spectrometry (ICP-MS).

When necessary, the $\mathrm{pH}$ of the solutions was varied by adding either $\mathrm{HClO}_{4}$ (Merck) or $\mathrm{NaOH}$ (Acros Organics). Experiments were carried out at two different ionic media: $0.1 \mathrm{moldm}^{-3}$ and $0.01 \mathrm{moldm}^{-3} \mathrm{NaClO}_{4}$ (Merck) both under oxic conditions (in synthetic air).

Two different series of experiments were carried out for each radionuclide: sorption kinetic experiments and sorption isotherm experiments.

In the first series, the evolution of the radionuclide concentration in solution was determined as a function of time in experiments with the same radionuclide concentration, weight of solid and $\mathrm{pH}$. For each radionuclide, two series of experiments, with different ionic medium $\left(0.01 \mathrm{~mol} \mathrm{dm}^{-3}\right.$ and $0.1 \mathrm{moldm}^{-3} \mathrm{NaClO}_{4}$, respectively), were carried out. The initial concentration of the radionuclide was $7.5 \cdot 10^{-7} \mathrm{~mol} \mathrm{dm}^{-3}$ in the case of cesium and $1.25 \cdot 10^{-5} \mathrm{moldm}^{-3}$ in the case of strontium. The solutions were put in contact with $0.05 \mathrm{~g}$ of uranophane. The different solutions of each series of experiments were in contact with the solid during different times. Once separated from the solid, each solution was filtered and final strontium or cesium concentrations were determined by ICP-MS.

In the second series, the evolution of the radionuclide concentration in solution was measured in different experiments with a variable initial concentration of the radionuclide and the same weight of solid and $\mathrm{pH}$ (sorption isotherms). Isotherms were carried out in a $0.01 \mathrm{~mol} \mathrm{dm}^{-3} \mathrm{Na}-$ $\mathrm{ClO}_{4}$ ionic medium, although some experiments were additionally carried out at $0.1 \mathrm{~mol} \mathrm{dm}^{-3}$ in order to corroborate the effect of the ionic strength observed in the kinetic experiments.

\section{Results and discussion}

\subsection{Kinetics of sorption and effect of the ionic strength}

Sorption kinetics experiments were performed in order to establish the time needed to reach the equilibrium in the sorption process (which was subsequently used in sorption isotherms experiments as the 
ending time). In addition, the knowledge of the rate of sorption contributes to evaluate the actual influence of the kinetics of the process on the radionuclides retention in the near-field of a high level nuclear waste repository (HLNWR), that is, whether the radionuclides retention process would be kinetically controlled.

The evolution of the amount of radionuclide sorbed on uranophane as a function of time is shown in Fig. 3. The percentage of sorption was calculated from the ratio between moles sorbed of radionuclide and moles initially present at the solution.

The main conclusion conveyed by the results obtained (Fig. 3) is that the sorption process is very fast for both radionuclides and at both ionic media. In the four experiments the equilibrium was reached before the first thirty minutes. Cesium sorption reaches equilibrium in less than $15 \mathrm{~min}$, compared, for example, with the sorption of cesium onto studtite, also considered relatively fast, with equilibrium times of $10 \mathrm{~h}$ [20]. On the other hand, the sorption of strontium is also faster on uranophane (equilibrium reached in more or less $0.5 \mathrm{~h}$ ) than on studtite (equilibrium reached in $2 \mathrm{~h}$ ) [21]. In addition, data in Fig. 3 also show that at the lowest ionic strength, the percentages of sorption are very high being $90 \%$ for both radionuclides, approximately, what points to a high sorption capacity of uranophane for both cesium and strontium.

Furthermore, for both radionuclides sorption decreased as the ionic strength increased. Sorption percentages drastically decreased from $90 \%$ to $50 \%$ for cesium and from $90 \%$ to $40 \%$ for strontium. The decrease of the sorption with the ionic strength increase is characteristic of the formation of outer-sphere complexes [22-24], involving electrostatic bonds, less stable than inner-sphere complexes, which form covalent bonds. Although the scatter of the data at the first hours of the experiments is relatively high, it seems that at high ionic strength, sorption increases during the first hours for both radionuclides, before decreasing until the equilibrium. This observation could be a result of the competition of the radionuclide and sodium for the sorption sites. The relatively high initial sorption of the radionuclides could be follow by a decrease of the sorption due to the slower sorption of sodium at such relatively high concentration, which would release the radionuclides to

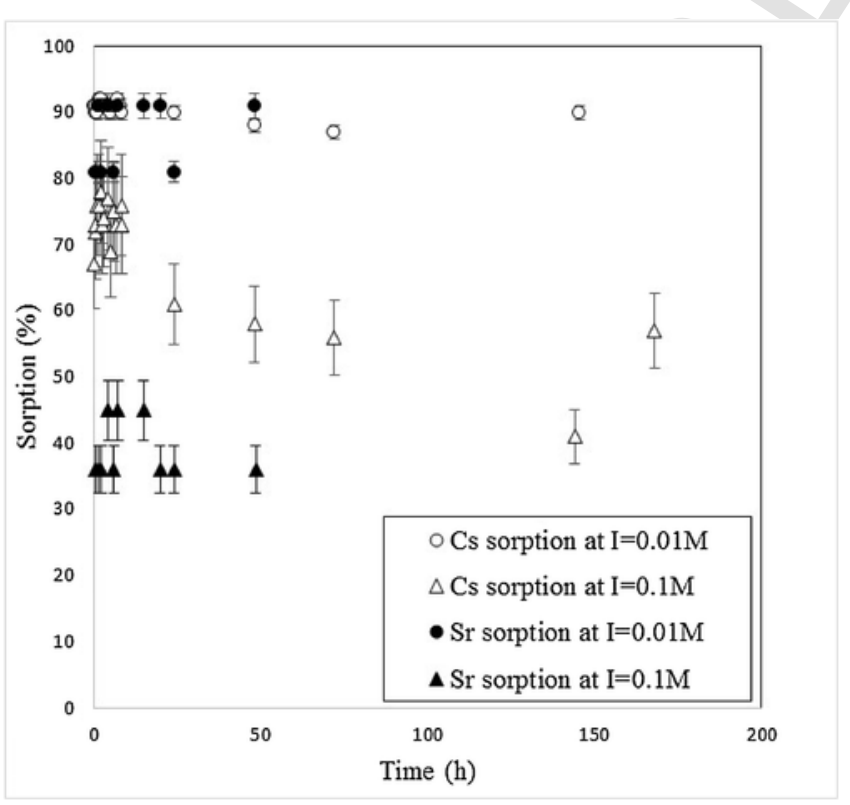

Fig. 3. Sorption of cesium and strontium onto uranophane as a function of time. Experiments with cesium: $[\mathrm{Cs}]_{0}=7.5 \cdot 10^{-7} \mathrm{~mol} \cdot \mathrm{dm}^{-3} ; \mathrm{pH}_{\mathrm{eq}}=8$ at ionic strength $0.01 \mathrm{~mol} \cdot \mathrm{dm}^{-3}$ and $\mathrm{pH}_{\mathrm{eq}}=7.0$ in series at ionic strength $0.1 \mathrm{~mol} \cdot \mathrm{dm}^{-3}$. Experiments with strontium: $[\mathrm{Sr}]_{0}=126 \cdot 10^{-5} \mathrm{~mol} \cdot \mathrm{dm}^{-3} ; \mathrm{pH}_{\mathrm{eq}}=8.4$. the solution and would slow down the reaching of the sorption equilibrium.

The low time required for equilibrium together with the high sorption capacity of the solid points to the adequate characteristics of uranophane to retain cesium and strontium. Considering the kinetic results obtained, the process of sorption/retention of the radionuclides released from the SNF would not be kinetically controlled.

\subsection{Sorption isotherms}

Sorption isotherms were carried out in order to have information on the sorption mechanism and in order to know the maximum sorption capacity of the uranophane for cesium and for strontium, which will be critical for the assessment of the actual sorption capacity of the solid for radionuclides released from the SNF.

The results obtained are shown in Fig. 4 for both radionuclides. As it can be seen, in both cases the higher the ionic strength the lower the sorption, indicating that the mechanism of cesium or strontium sorption is affected by the ionic medium and corroborating the influence of the ionic strength on the sorption observed in the kinetics experiments. On the other hand, there is a linear dependency of the sorption with the equilibrium radionuclide concentration in solution until relatively high concentrations. The sorption then remains independent on the equilibrium concentration in solution. The shape of the isotherms is consistent with a Langmuir sorption model, indicating a mechanism of sorption based on a monolayer coverage on the uranophane surface, meaning that the radionuclides are sorbed until all the sorption surface sites of the solid are occupied. Fig. 4 also shows the fitting of the Langmuir isotherm to the experimental data. The model is based on the relationship between sorption capacity $\left(\{\mathrm{RN}\}\right.$, in $\left.\mathrm{mol} \cdot \mathrm{m}^{-2}\right)$ and radionuclide concentration in solution at equilibrium ([RN], in $\mathrm{moldm}^{-3}$ ),
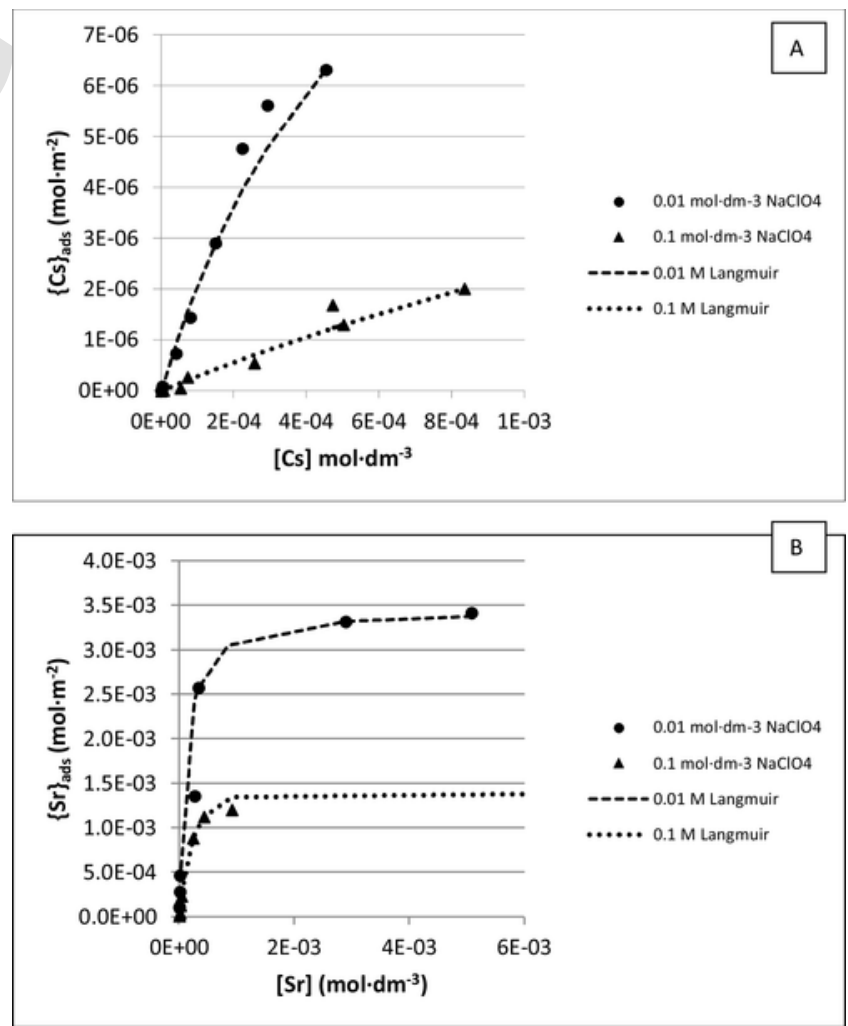

Fig. 4. Experimental results of the cations adsorption onto uranophane as a function of the ion concentration in the solution and ionic strength: (A) cesium and (B) strontium. In each graph, plots the adsorption data under 0.01 of ionic strength and $\mathbf{A}$ plots the data under 0.1 of ionic strength. 
given by Eq. (1).

$$
\{\mathrm{RN}\}=\{\mathrm{RN}\}_{\max } \frac{\mathrm{K}_{\mathrm{L}} \cdot[\mathrm{RN}]}{1+\mathrm{K}_{\mathrm{L}} \cdot[\mathrm{RN}]}
$$

where ' $\mathrm{K}_{\mathrm{L}}$ ' is the Langmuir constant $\left(\mathrm{dm}^{3} \mathrm{~mol}^{-1}\right)$ and ' $\{\mathrm{RN}\}_{\max }$ ' is the maximum radionuclide sorption $\left(\mathrm{mol} \mathrm{m}^{-2}\right)[25,26]$. The fitting of the model to the experimental data gave the $\mathrm{K}_{\mathrm{L}}$ and $\{\mathrm{RN}\}_{\max }$ values shown in Table 1. Maximum sorption capacities increase with the decrease of the ionic strength, and are two orders of magnitude higher for strontium than for cesium, which is in agreement with assuming electrostatic interactions between the cations in solution and the surface of the solids, interactions that are stronger for divalent cations than for monovalent cations. This was also observed in batch experiments on sorption of cesium and strontium onto studtite, where the sorption of strontium was always higher than the sorption of cesium [20,21].

\subsection{Potential impact of the formation of uranophane in a HLNWR}

The main objective of this work was to determine the extent of sorption of cesium and strontium on uranophane, that would prevent the release of such radionuclides to the groundwaters, and further to the biosphere, once they are released from the SNF. The effect of the presence of uranyl silicates and, in particular, uranophane, in the SNF near field has to be considered because of their likely formation as alteration products of the $\mathrm{UO}_{2}$ matrix. The experiments carried out by Wronkiewicz et al. [27] on the $\mathrm{UO}_{2}$ alteration in the presence of silicate showed that uranyl silicates such as uranophane (and, depending on calcium, potassium and magnesium concentrations in solution, also boltwoodite, and sklodowskite, $\left.\mathrm{Mg}\left(\mathrm{UO}_{2}\right)_{2}\left(\mathrm{HSiO}_{4}\right)_{2} \cdot 5 \mathrm{H}_{2} \mathrm{O}\right)$ predominated after two years of contact between $\mathrm{UO}_{2}$ and the Si-rich solutions, although they were not the solid phases formed on a first stage. The long-term predominance of uranophane (one of the most abundant uranium minerals [28]) as a secondary solid phase in non-irradiated $\mathrm{UO}_{2}$ experiments agrees with the results obtained in long-term experiments on the alteration of SNF in contact with Si-containing waters [4,5]. Actually, the secondary solid phases observed in experiments with $\mathrm{SNF}, \mathrm{UO}_{2}$ and natural analogue deposits, suggest that alkali and alkaline earth uranyl silicates are the long-term solubility-limiting phases for uranium [29]. Considering the long-term predominance of uranyl silicates such as uranophane, the determining step on the radionuclides incorporation to the secondary solid phases would be the process of uranyl silicate formation. This work shows that the incorporation of cesium and strontium is very fast and most cesium and strontium in solution were sorbed on the surface of the solid in less than thirty minutes. In other words, once formed, uranophane would rapidly sorb both radionuclides.

On the other hand, the range of cesium and strontium concentrations studied in this work comprises the actual cesium and strontium concentrations released from SNF in leaching experiments: $10^{-7}-5 \cdot 10^{-6} \mathrm{~mol} \mathrm{dm}^{-3}$ for cesium and $5 \cdot 10^{-8}-10^{-5} \mathrm{moldm}^{-3}$ for strontium [30-33]. At such ranges of concentration, experimental data obtained in this work indicate that sorption is favoured for both radionuclides.

Table 1

Determined values for the Langmuir model parameters.

\begin{tabular}{llll}
\hline Cation & \multicolumn{3}{l}{ Langmuir } \\
& $\mathrm{K}_{\mathrm{L}}$ & $\{\mathrm{RN}\}_{\mathrm{e}}$ & $\mathrm{R}^{2}$ \\
\hline Cesium (0,1 ionic strength) & 276 & $1,07 \cdot 10^{-5}$ & 0,9886 \\
Cesium (0,01 ionic strength) & 1561 & $1,53 \cdot 10^{-5}$ & 0,9952 \\
Strontium (0,1 ionic strength) & 4979 & $1,65 \cdot 10^{-3}$ & 0,9857 \\
Strontium (0,01 ionic strength) & 8933 & $3,45 \cdot 10^{-3}$ & 0,9851 \\
\hline
\end{tabular}

This is of particular importance in the case of strontium, because ${ }^{90} \mathrm{Sr}$ was considered as an indicator for the SNF matrix degradation [21,34], due to its homogeneous distribution in the SNF and the lack of strontium solid phases that could precipitate in the chemical conditions of the groundwaters. The decrease of the strontium concentration in solution because of its likely incorporation to uranophane or other secondary solid phases, requires to consider sorption processes in order to establish its actual role as a useful indicator of the fuel matrix dissolution.

\section{Conclusion}

The results obtained in this work reinforce the role of uranyl secondary solid phases formed on the surface of the spent nuclear fuel to retain radionuclides released from the SNF. Sorption of radionuclides on uranyl silicates and, in particular, on uranophane, should be considered when establishing the migration of radionuclides from the near field of a HLNWR, in particular for radionuclides not retarded by other mechanisms such as precipitation or co-precipitation. At relatively low concentrations in solution, sorption could be the main retention mechanism for such radionuclides.

\section{Acknowledgments}

A. Espriu Gascon thanks to BES-2012-053098 for her fellowship from the Ministerio de Economía y Competitividad (Spain). This study has also been financially supported by ENRESA and Ministerio de Economía y Competitividad (Spain) with the projects ENE2014-54299-C2-1-R and CTM2011-27680-C02-01.

\section{References}

[1] C.N. Wilson, Summary of results from the series 2 and 3 NNSWI bare fuel dissolution tests, MRS Proc., 1988473-483.

[2] C.N. Wilson, Results from NNWSI [Nevada nuclear waste storage investigations], Series 2 Bare Fuel Dissolution Tests, 1990https://doi.org/10.2172/137899, Richland, Washington, USA.

[3] C.N. Wilson, Results from NNWSI Series 3: Spent Fuel Dissolution Tests, Richland, Washington, USA 1990.

[4] P.A. Finn, R. Finch, E. Buck, J. Bates, Corrosion mechanisms of spent fuel under oxidizing conditions, MRS Proc., MRS (1997) 123-131, https://doi.org/10.1557/ PROC-506-123.

[5] R.J. Finch, M.L. Miller, R.C. Ewing, Weathering of natural uranyl oxide hydrates: schoepite polytypes and dehydration effects, Radiochim. Acta 58/59 (1992) 433-443, https://doi.org/10.1524/ract.1992.5859.2.433.

[6] Z. Wang, J.M. Zachara, P.L. Gassman, C. Liu, O. Qafoku, W. Yantasee, J.G. Catalano, Fluorescence spectroscopy of U(VI)-silicates and U(VI)-contaminated Hanford sediment, Geochim. Cosmochim. Acta 69 (2005) 1391-1403, https://doi.org/10. 1016/j.gca.2004.08.028.

[7] D.W. Shoesmith, Fuel corrosion processes under waste disposal conditions, J. Nucl. Mater. 282 (2000) 1-31, https://doi.org/10.1016/S0022-3115(00)00392-5.

[8] P.C. Burns, K.M. Deely, S. Skanthakumar, Neptunium incorporation into uranyl compounds that form as alteration products of spent nuclear fuel: implications for geologic repository performance, Radiochim. Acta 92 (2004) 151-160, https://doi. org/10.1524/ract.92.3.151.30491.

[9] M. Douglas, S.B. Clark, S. Utsunomiya, R.C. Ewing, Cesium and strontium incorporation into uranophane, $\mathrm{Ca}\left[\left(\mathrm{UO}_{2}\right)\left(\mathrm{SiO}_{3} \mathrm{OH}\right)\right]_{2} \cdot 5 \mathrm{H}_{2} \mathrm{O}$, J. Nucl. Mater. (2002) 504-507, https://doi.org/10.1080/00223131.2002.10875517.

[10] United States Environmental Protection Agency, Radionuclide Basics: Strontium-90, 2015 http://www.epa.gov/radiation/radionuclide-basics-strontium-90.

[11] E. Wieland, J. Tits, D. Kunz, R. Dähn, Strontium uptake by cementitious materials, Environ. Sci. Technol. 42 (2008) 403-409, https://doi.org/10.1021/es071227y.

[12] E.A. Martell, Atmospheric aspects of strontium-90 fallout, Science 129 (80) (1959) 1197-1206.

[13] H. Nishioka, Y. Kato, Y. Nishiwaki, Influence of calcium and strontium carriers for radioactive strontium deposition in bone, J. Radiat. Res. 3 (1962) 170-176.

[14] S.N. Nguyen, R.J. Silva, H.C. Weed, J.E. Andrews, Standard gibbs free energies of formation at the temperature $303.15 \mathrm{~K}$ of four uranyl silicates: soddyite, uranophane, sodium boltwoodite, and sodium weeksite, J. Chem. Thermodyn. 24 (1992) 359-376, https://doi.org/10.1016/S0021-9614(05)80155-7.

[15] B. Lafuente, R.T. Downs, H. Yang, N. Stone, The power of databases: the RRUFF project, in: T. Armbruster, R.M. Danis (Eds.), Highlights Mineral. Crystallogr., W. De Gruyter, Berlin, Germany, 2015, pp. 1-30.

[16] K. Bourikas, J. Vakros, C. Kordulis, A. Lycourghiotis, Potentiometric mass titrations: experimental and theoretical establishment of a new technique for determining the point of zero charge (PZC) of metal (hydr)oxides, J. Phys. Chem. B 107 (2003) 9441-9451, https://doi.org/10.1021/jp035123v. 
[17] N. Fiol, I. Villaescusa, Determination of sorbent point zero charge: usefulness in sorption studies, Environ. Chem. Lett. 7 (2008) 79-84, https://doi.org/10.1007/ s10311-008-0139-0.

[18] J. Giménez, J. de Pablo, I. Casas, X. Martínez-Lladó, M. Rovira, A. Martínez Torrents, Solubility study and point of zero charge of studtite $\left(\mathrm{UO}_{2} \mathrm{O}_{2} \cdot 4 \mathrm{H}_{2} \mathrm{O}\right)$, Appl. Geochemistry 49 (2014) 42-45, https://doi.org/10.1016/j.apgeochem.2014.07. 004.

[19] J. Giménez, R. Sureda, J. De Pablo, I. Casas, X. Martinez-Llado, M. Rovira, A. Martinez-Esparza, The role of uranium peroxide studtite on the retention of $\mathrm{Cs}, \mathrm{Sr}$ and Se(VI), MRS Proc. (2009) 621-626, https://doi.org/10.1557/PROC-1193-621.

[20] J. Giménez, X. Martínez-Lladó, M. Rovira, J. de Pablo, I. Casas, R. Sureda, A. Martinez-Esparza, Cesium sorption on studtite $\left(\mathrm{UO}_{2} \mathrm{O}_{2} \cdot 4 \mathrm{H}_{2} \mathrm{O}\right)$, Radiochim. Acta98 (2010) 479-483, https://doi.org/10.1524/ract.2010.1742.

[21] R. Sureda, X. Martínez-Lladó, M. Rovira, J. de Pablo, I. Casas, J. Giménez, Sorption of strontium on uranyl peroxide: implications for a high-level nuclear waste repository, J. Hazard. Mater. 181 (2010) 881-885, https://doi.org/10.1016/j.jhazmat. 2010.05.095.

[22] L. Sigg, K.-U. Goss, S. Haderlein, H. Harms, S.J. Hug, C. Ludwig, Sorption phenomena at environmental solid surfaces, Chimia (Aarau) 51 (1997) 893-899.

[23] A.P. Robertson, J.O. Leckie, Cation binding predictions of surface complexation models: effects of $\mathrm{pH}$, ionic strength, cation loading, surface complex, and model fit, J. Colloid Interf. Sci. 188 (1997) 444-472, https://doi.org/10.1006/jcis.1996. 4752.

[24] T.D. Small, L.A. Warren, F.G. Ferris, Influence of ionic strength on strontium sorption to bacteria, Fe ( III ) oxide and composite bacteria-Fe ( III ) oxide surfaces, Appl. Geochemistry 16 (2001) 939-946, https://doi.org/10.1016/ S0883-2927(00)00065-2.

[25] J. Giménez, M. Martínez, J. de Pablo, M. Rovira, L. Duro, Arsenic sorption onto natural hematite, magnetite, and goethite, J. Hazard. Mater. 141 (2007) 575-580, https://doi.org/10.1016/j.jhazmat.2006.07.020.

[26] M. Rovira, J. Giménez, M. Martínez, X. Martínez-Lladó, J. de Pablo, V. Martí, L. Duro, Sorption of selenium(IV) and selenium(VI) onto natural iron oxides: goethite and hematite, J. Hazard. Mater. 150 (2008) 279-284, https://doi.org/10.1016/j. jhazmat.2007.04.098.

[27] D.J. Wronkiewicz, J.K. Bates, T.J. Gerding, E. Veleckis, B.S. Tani, Uranium release and secondary phase formation during unsaturated testing of $\mathrm{UO} 2$ at $90^{\circ} \mathrm{C}$, J. Nucl. Mater. 190 (1992) 107-127, https://doi.org/10.1016/0022-3115(92)90081-U.

[28] R.J. Finch, T. Murakami, Systematics and paragenesis of uranium minerals, in: P.C. Burns, R. Finch (Eds.), Uranium Mineral. Geochemistry Environ., Mineralogical Society of America USA, 1999, pp. 89-179.

[29] D.J. Wronkiewicz, J.K. Bates, S.F. Wolf, E.C. Buck, Ten-year results from unsaturated drip tests with $\mathrm{UO}_{2}$ at $90^{\circ} \mathrm{C}$ : implications for the corrosion of spent nuclear fuel, J. Nucl. Mater. 238 (1996) 78-95, https://doi.org/10.1016/ S0022-3115(96)00383-2.

[30] J. de Pablo, I. Casas, J. Giménez, F. Clarens, E. González-Robles, D. Serrano-Purroy, J.-P. Glatz, D. Wegen, B. Christiansen, A. Martínez-Esparza, Contribution to leaching studies of high-burnup spent nuclear fuel, Las Vegas, USA, 12th Int. High-Level Radioact. Waste Manag. Conf. (2008).

[31] D. Serrano-Purroy, F. Clarens, E. González-Robles, J.P. Glatz, D.H. Wegen, J. de Pablo, I. Casas, J. Giménez, A. Martínez-Esparza, Instant release fraction and matrix release of high burn-up $\mathrm{UO}_{2}$ spent nuclear fuel: effect of high burn-up structure and leaching solution composition, J. Nucl. Mater. 427 (2012) 249-258, https:// doi.org/10.1016/j.jnucmat.2012.04.036.

[32] D. Serrano-Purroy, F. Clarens, J.-P. Glatz, D. Wegen, B. Christiansen, J. De Pablo, J. Gimenez, I. Casas, A. Martínez-Esparza, Leaching of 53 MW/d kg U spent nuclear fuel in a flow-through reactor, Radiochim. Acta 97 (2009) 491-496, https:// doi.org/10.1524/ract.2009.1640.

[33] J. De Pablo, D. Serrano-Purroy, E. Gonzalez-Robles, F. Clarens, A. Martinez-Esparza, D.H. Wegen, I. Casas, B. Christiansen, J.P. Glatz, J. Gimenez, Effect of HBS structure in fast release fraction of $48 \mathrm{GWd} / \mathrm{tU}$ PWR fuel, MRS Proc., 2009613-620, https://doi.org/10.1557/PROC-1193-613.

[34] B. Grambow, A. Loida, H. Geckeis, I. Casas, M.E. Torrero, J. Gimenez, J. de Pablo, J. Gago, Direct disposal of spent fuel: chemistry of reactions, Report EUR-17543, 1997, Luxembourg. 